An Investigation into the Causes of Sexual Abuse (Promiscuity) among Female Students in a Selected Tertiary Institution in Adamawa State, Nigeria.

\author{
Yusuf Abdullahi ${ }^{\mathrm{a}}$, Mom Saa-Aondo ${ }^{\mathrm{b}}$. \\ ${ }^{a}$ myusufabdullahi48@gmail.com \\ Department of Mechanical Engineering, School of Engineering Technology Adamawa State \\ Polytechnic, Yola Adamawa state, 640283, Nigeria \\ +2347036050297 . \\ b momsaaaondo@gmail.com \\ Precious AcademyJambutu Jimeta Yola, Adamawa State, 640283, Nigeria. \\ +2348065802051 .
}

\begin{abstract}
Sexual abuse (promiscuity) in tertiary institutions constitutes a sociological problem in the society today. To investigate the causes of sexual abuse among female students in a selected tertiary institution in Adamawa state, a questionnaire was drawn up guided by two research questions coming from two objectives for the study. Descriptive survey design was adopted for the study and final year female students and lecturers/administrators constituted the population for the study which was two hundred respondents. Questionnaires were issued to them after which the data collected from the respondents was analyzed using descriptive statistics. The study revealed that there are certain behaviors which constitute sexual abuse among female students in the institution; also it was found that economic factors, personal factors and organizational factors are the causes of sexual abuse among female students in the tertiary institution of learning. The research recommended among others, creation of jobs for job seekers by the Government and other stakeholders; award of scholarships by both the Government and other stakeholders and enactment of laws against promoters of sexual abuse (i.e. purchasers, pimps, owners of brothels, lecturers e t c).
\end{abstract}

Key Words: Sexual abuse; tertiary institutions promiscuity.

\title{
Introduction
}

Sexual abuse also known as prostitution or promiscuity is the act of indulging in or having sexual intercourse with several casual acquaintances (Okafor and Duru, 2010:100). According to Wehmeier, (2000), prostitution means having sexual partners. Misi, (2008) opined that prostitution is the use of one's body for the purpose of remuneration or consideration of any form. This is a type of service given by ladies who want money or who are desperate to attain some certain level of prosperity (Osoba, 1995). Geis (2000) defined prostitution as the performance of sexual acts with another person in return for payment of fee, also the World Health Organization (WHO) defined prostitution as a process that involves a transaction between a seller and buyer of a sexual service (World Health Organization, 1988). Persons who make a living or supplement their income from prostitution usually are willing to engage in sexual activity with most persons who can pay them. Prostitutes sometimes have also been known to impose hygienic, age, health, or racial and ethnic criteria on their acceptance of customers. Prostitution involves payment for a specific act. For example, a call girl responds to a telephone solicitation to engage in a sexual act with a client in his hotel room, and is paid for doing so. But some related kinds of behavior are not as readily classifiable as prostitution. For instance, a person performing sexual acts in exchange for gifts or in the hope of future favors generally is not classified by definition as a prostitute. Similarly, a woman who engages in sexual intercourse in front of a photographer for a mass circulation magazine is apt to regard herself as

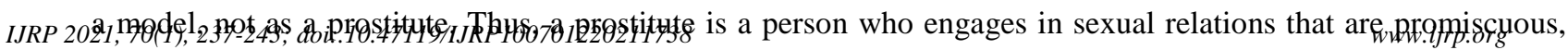
fairly indiscriminate, largely without affection, often anonymous not made legitimate by marriage (Kangiwa, 2015). 
Observations by researchers have shown that many female students in tertiary institutions are in this practice. According to them, it is more lucrative now as a student in the campus because men no longer patronized brothels and street prostitutes rather they prefer students. The campus situation is so bad to the extent that professional prostitutes are hail bent to gain admission into higher institutions (Okafor and Duru, 2010: 100).

In addition to this, Uzokwe (2008) posited that with unbridled liberty and freedom the students began to push the limits of acceptable behavior, taking advantage of freedom bestowed on them as "adults".At this point, one would ask, what is the actual cause of sexual prostitution or prostitution among our female undergraduates? (Okafor and Duru, 2010: 100). Although there are many motivating factors for students' engagement in prostitution, Onwubiko and Okonkwo (2013) believes that inordinate desire for affluence and desperation by many Nigerians, especially young ladies in campuses are the motivating factors for them to be consistently lured and engaged in sexual explicit acts. According to Uzokwe (2008), one of the causes is dereliction of parental responsibilities. Many years ago, families in Nigeria put a lot of premium on morality, honor and character. Parents took time to bequeath same to their wards during their formative years. There were injunctions and periodic denial of basic necessities for doing things that impinge the family name. Vices like prostitution, stealing and the like when displayed by a member of the family are capable of soiling the family image. No family would want to be blacklisted or blackmailed so parents paid serious attention to the moral and social welfare of their children, at times taking corrective actions when bad behaviors were detected. Compare this day to the ages past, certain behaviors that would repulse people no longer do. The reverse seems to be the case.

On the other hand, teachers these days no longer play the invaluable traditional roles they used to. They are no longer character builders because children have grown „wings and tails ${ }^{\mathrm{ee}}$. These children, especially the female ones, feel they have the protection of their parents and or boyfriends. Consequently, young girls go through school exhibiting signs of unacceptable behavior which metamorphose into bigger issues in future with no one to stop or correct them. Eventually, those who find their ways into the higher institutions end up continuing on a larger scale what they started in secondary schools.

Furthermore, some tertiary institutions (universities, polytechnics, colleges of education) are not helping matters. Their fees are so much that it is hard to understand where they expect the students to get the money from. Being in a precarious condition, they turn to prostitution based on the fact that they are looking for money to settle their school bills. Prostitution has assumed a more sinister dimension with the invasion of the tertiary institutions by older male members of the privileged class to fetch girls from the school to be used as commercial sex workers (Mume, 2017). Misi (2008), also pointed out that the politicians and government officials are not left out in the cause of female student's "sexual abuse" (prostitution). According to him, anytime these politicians and government officials visit the university town on official work, the pimps recruit for them young university girls for their relaxation and entertainment, at the end of which they settle them with huge sums of ill-gotten money (Olugbogega, 2008). Due to the fact that the girls glorify wealth, some of them therefore do what it takes to belong by taking to prostitution. James and Meyerding (1978) in their study concluded that early sexual experience is an important factor on one becoming a prostitute in later life. The authors are also of the view that being in an abusive relationship can lead one to becoming a prostitute.

On the issue of the effect of sexual abuse (prostitution) on healthy living, Janice (2008) intimated that sexually transmitted diseases like gonorrhea, syphilis, Candida, herpes virginalis and worst of all HIV/AIDS are alarmingly high among girls who are into prostitution. Drugs like cocaine, marijuana and alcohol are used most frequently by these girls at the expense of their health. They are also mostly under the influence of "psychotropic drugs" that put them in a state of fearlessness and shamelessness. In the same vein, Gultmacher (1988) opined that most cases of infertility are caused by being into prostitution thereby being infested by numerous infected customers or acquaintances. Most female or male infertility, he added, can be attributed to husbands or wives who patronize sex hawkers and bring home infections and sexually transmitted diseases. In what becomes a vicious cycle, infertility may lead to divorce and in some cases the abandoned wife goes into prostitution as a means of survival. Again, physical injuries and bruises may also lead to general break down in health condition. Furthermore, most of the girls in this practice are sometimes physically assaulted by their "purchasers" who might be acting under the influence of hard drugs (Janice, 2008). 
This work is anchored on social learning theory propounded by Albert Bandura (1925) as recorded in Oyeoku (2012). This theory holds that people learn from one another, including such concepts as observational learning, imitation and modeling. By implication therefore, social learning theory demonstrate that promiscuity may be a learned behaviour. For instance, if a child is exposed to an environment where people practice promiscuity; this may increase the tendency of the child engaging in promiscuity. Female students can learn promiscuity from parents, elderly ones or friends.

The purpose of this study is to investigate the causes and effects of sexual abuse (promiscuity) among female students in a selected tertiary institution in Adamawa State Nigeria

The objectives of the study were to:

- Determine what constitute sexual abuse (promiscuity) among female students in a selected tertiary institution in Adamawa State Nigeria.

- Investigate the causes of sexual abuse (promiscuity) among female students in a selected tertiary institution in Adamawa State Nigeria.

The following research questions were formulated to guide the study.

- What constitutes sexual abuse (promiscuity) in a selected tertiary institution in Adamawa State Nigeria?

- What are the causes of sexual abuse (promiscuity) in the selected tertiary institution in Adamawa State Nigeria?

\section{Research Design and Methodology.}

The design of the study was a descriptive survey type. This design is suitable for this research because it will seek to describe the three variables (effects and solutions) of sexual abuse (prostitution) in relation to the female population in the Adamawa state tertiary institution. The population of the study covered two hundred respondents comprising of one hundred and fifty final year female students and fifty administrators/lecturers. This is because they have ample experiences of activities in the polytechnic. The sample of the study consisted of two hundred respondents. To compose this sample, a stratified/proportionate random sampling technique was employed to ensure that each sample will be representative of the population so that the result can be generalized.

The instrument used for data collection was questionnaire titled: Effects of Sexual Abuse among Female Students in the Adamawa State Tertiary Institution (ESAAFSASTI). The questionnaire items were developed through the information gotten from reviewed literature. The questionnaire contained questions which were divided into two major sections. Section A was for the first respondents (final year female students). Section B was for the second respondents (Lecturers and School Administrators) and addressed the possible solutions to the problem of sexual abuse (promiscuity). A 5-point Likert scale of Strongly Agree ( $\mathrm{SA}=5$ points), Agree (A = 4 points), Fairly agree ( $F A=3$ points), Disagree ( $\mathrm{D}=2$ point) and Strongly disagree ( $\mathrm{SD}=1$ point) was adopted and the mean determined for each questionnaire item. Any mean above 2.4 was taken as strongly accepted while any mean below 2.4 was taken as strongly disagreed.

The instrument was validated by three experts. One of the experts was in Measurement and Evaluation, one in Sociology of Education and one from Guidance and Counseling unit of the institution. To determine the reliability of the test instrument, Effects of Sexual Abuse Among Female Students in a tertiary institution in Adamawa state (ESAAFSASTI) was trial tested using two groups of students comprising ten newly enrolled students each who were not part of the target group in this research. The results were correlated using Pearson product moment correlation approach. The result yielded the coefficient of $r=0.74$. This score indicates that the instrument is reliable.

The questionnaire was administered to the respondents by the researcher and one trained research assistant. The respondents were allowed to fill the questionnaire and return them to the researcher and his assistant after which, the data was analyzed using descriptive statistics (percentages frequencies and tables). 


\section{Findings}

Research Question 1: What constitute sexual abuse among female students in the selected?

Table 1: What constitute sexual abuse? $(\mathrm{N}=200)$

\begin{tabular}{|c|c|c|c|c|c|c|c|}
\hline \multirow[t]{2}{*}{ S/No } & \multirow[t]{2}{*}{ Items } & \multicolumn{5}{|c|}{ Responses } & \multirow[b]{2}{*}{$\%$} \\
\hline & & SA/A & $\%$ & FA & $\%$ & $\mathrm{D} / \mathrm{SD}$ & \\
\hline 1 & Female students engaged in sex with their boyfriends. & 125 & 62.5 & 45 & 22.5 & 30 & 15 \\
\hline 2 & Female students exchange sex for marks. & 65 & 32.5 & 35 & 17.5 & 100 & 50 \\
\hline 3 & $\begin{array}{l}\text { Female students stand in front of their hostels or school gate } \\
\text { at night to seek male customers. }\end{array}$ & 132 & 66.0 & 18 & 9 & 50 & 25 \\
\hline 4 & $\begin{array}{l}\text { Female students go to nearby cities or towns for maximum } \\
\text { exposure to men. }\end{array}$ & 68 & 34 & 52 & 26 & 80 & 40 \\
\hline \multirow[t]{3}{*}{5} & $\begin{array}{l}\text { Female students are hired to attend parties and functions } \\
\text { where they are paid for services rendered including sex. }\end{array}$ & 80 & 40 & 40 & 20 & 80 & 40 \\
\hline & Total & 470 & 235 & 190 & 95 & 340 & 170 \\
\hline & Average & 94 & 47 & 38 & 19 & 68 & 34 \\
\hline
\end{tabular}

KEY: SA = Strongly agree; A = Agree; $\mathrm{D}=$ Disagree; $\mathrm{SD}$ = Strongly disagree.

Table one (1) above had five questionnaire items which sought out the existence of certain behaviors that constitute sexual abuse among female students in the polytechnic. The result revealed that $47 \%$ (94 respondents) agreed that such behaviors constitute sexual abuse (promiscuity); $38 \%$ (28 respondents) fairly agreed that such behaviors constitute sexual abuse while 34\% (68 respondents) disagreed that such behaviors constitute sexual abuse in the polytechnic. It was therefore concluded that such behavior constitute sexual abuse among female students in the tertiary institution.

Result in table 2 showed the various causes of sexual abuse. It revealed that on average, 50.8\% (approx. 102 respondents) agreed that poverty, sex for marks, lack of contentment, laziness among female students, peer influence dereliction of roles by parents, lecturers, religious organizations and influence of clubs and societies are causes of sexual abuse among female students in the polytechnic; 18.3\% (approximately 37 respondents) fairly agreed to causes while $30.6 \%$ (approx. 59 respondents) disagreed that the items in the table are the causes of sexual abuse. The table also showed that based on the individual items, $80 \%$ (160 respondents) agreed that peer influence is a great cause of sexual abuse while $47 \%$ (95 respondents) disagreed to questionnaire item which said influence of clubs and societies is a cause of sexual abuse (Table 2). 
Research Question 2: What are the causes of sexual abuse in the selected tertiary institution?

Table 2: Causes of sexual Abuse among female students. $(\mathrm{N}=200)$

\begin{tabular}{llllllll}
\hline S/No Items & \multicolumn{3}{c}{ Responses } & & \\
& & SA/A & $\%$ & FA & $\%$ & D/SD & $\%$ \\
\hline & & & & & & & \\
1 & Poverty & 155 & 75.5 & 15 & 7.5 & 30 & 15 \\
2 & Sex for marks & 110 & 55 & 35 & 17.5 & 55 & 27.5 \\
3 & Lack of contentment (greed) & 65 & 32.5 & 40 & 20 & 95 & 47.5 \\
4 & Laziness among female students. & 55 & 27.5 & 60 & 30 & 85 & 42.5 \\
5 & Peer influence & 160 & 80 & 20 & 10 & 20 & 10 \\
6 & Dereliction of roles by parents. & 110 & 55 & 40 & 20 & 50 & 25 \\
7 & Dereliction of roles by lecturers & 90 & 45 & 20 & 10 & 70 & 45 \\
8 & Dereliction of roles by Religious organizations. & 120 & 60 & 50 & 25 & 30 & 15 \\
9 & Influence of clubs and societies. & 55 & 27.5 & 50 & 25 & 95 & 47.5 \\
& Total & 920 & 458 & 330 & 165 & 530 & 275 \\
& Average & 102.2 & 50.8 & 36.6 & 18.3 & 58.9 & 30.6 \\
\hline
\end{tabular}

KEY : SA = Strongly agree $; \mathrm{A}=$ Agree $; \mathrm{D}=$ Disagree $; \mathrm{SD}=$ Strongly disagree .

\section{Discussion of Findings and Conclusion}

Table one showed the result of the respondents on certain behaviors that constitute sexual abuse in the investigated tertiary institution. The result showed that most of the respondents (47\%; 94 respondents) agreed that female students engage in sex with their boyfriends, they exchange sex for marks, they stand in front of their hostels or school gate at night to seek male customers, female students go to to nearby cities or towns for maximum exposure to men and female students are hired to attend parties and functions where they are paid for services rendered including sex. These findings corroborate with Uzokwe (2008) who posited that prostitution is very rampant in Nigerian universities. He said that our young girls sent to the universities to acquire knowledge and become productive citizens found a vocation in prostitution. Misi ((2008) added that professional prostitutes are everywhere in the campuses as undergraduates, because according to him "men now prefer students to street prostitutes". Olugbile, et al, (2008) opined that female students now trade with their bodies to earn huge income. Also, Oyeoku et al, (2014), Okafor and Duru (2015) reported a similar trend of prostitution in higher institutions of learning. The results also revealed that high number of respondents $(50 \% ; 100$ respondents) disagree to questionnaire item two which says female students exchange sex for marks. This is contrary to the view of Kangiwa (2015) who opined that female students exchange sex for marks.

Answers to the questionnaire items to research question two (Table two) which sought to find out the causes of sexual abuse among female students showed that higher percentage of the respondents agreed that poverty, sex for assessment marks, lack of contentment(greed), laziness among female students, peer influence, dereliction of roles by parents, lecturers and religious organizations and influence of clubs and societies are the causes of sexual abuse among female students in tertiary institution. These results corroborates with that of several researchers such as Okafor and Duru, (2010), Oyeoku, (2012), Gungul et al, (2014), Oyeoku et al, (2014), Kangiwa, (2015), Hussaini, (2016), and Ukaegbu et al, (2017) have in their separate researches reported among others poverty, sex for marks, laziness among female students, peer influence, dereliction of roles by parents, lecturers and religious organizations are the reasons for prostitution. This could be due to the fact that some parents can't afford the cost of providing for their children's while in school, high amount of fees among other charges charged by the various higher institutions of learning (Okafor and Duru, 2010), the invasion of the tertiary institutions by older male members of the privileged class to fetch girls from the school to be used as commercial sex workers, (Mrume, 2017). Uzokwe, (2008) also assert that prostitution has become a lucrative business in higher institutions of 
learning. In his contribution, Olugbogega, (2008) opined that economic crises and unemployment contribute to prostitution by female students.

Certain behaviors which constitute sexual abuse among female students exist in the institution; also it was found that economic factors, personal factors and organizational factors are the causes of sexual abuse among female students in the tertiary institution. It is therefore concluded that sexual abuse (promiscuity) not just not in the tertiary institution is a cancer that must be nipped from the bud for the well-being of not just the institution but the society in general.

The following recommendations are made based on the findings of this study.

- Government should and must adopt strategies to increase the inflow of revenue and the creation of jobs for qualified job seekers. Economic policies that will create a robust economy should be introduced by government, especially policies that will boast inflow of and opening of business opportunities.

- Undertaking oath by both parents and students against indecent dressing should be signed and students who violate the rule should be disciplined.

- Parents should try their possible best to provide for their children while they are in school, also, students on the other hand should be contented with what they have and avoid bad friends.

- Scholarships should be given to students by both the Government and others stakeholders as this will discourage them from engaging into sexual abuse.

- Religious groups (churches, mosques etc.) on campus should also begin to educate these students on arrival and the effects of sexual abuse on academics as well as relationship with God.

- Laws should be made against people who promote sexual abuse (i.e. purchasers, pimps, owners of brothels, lecturers' e t c).

\section{References}

Alobo, E., Rita, N., 2014. Addressing prostitution concerns in Nigeria: issue, problems and prospects. European Scientific Journal May 2014 edition , 10:14, ISSN: 1857 - 7881 (Print) e - ISSN 1857- 7431.

Bahago, F.J.S., 2013. Manpower Training and Development and HIV/AIDS: The Challenges. Journal of Public Administration, 3(1).

Geis, G., 2000. Prostitution: International Edition. Encyclopaedia-Americana. Danbury, Grolier, 22, 669-670.

Gultmacher, A. Institute publication., 1988 Young women sexuality reproductive lives, htpp://www.com.about.comm.

Gungul, T.T., Samson A.J., 2014. Prostitution as a Social Evil in Nigeria: Issues and Challenges, International Journal of Peace and Conflict Studies, 2:1, 29-36.

James, J., Meyerding, J., 1978. Early sexual experience as a factor in prostitution, Journal Archives of Sexual Behavior, 71, 31-42.

Janice, G.R., 2008. Making the harm visible Global speaking out and providing services, Health Effects of Prostitution. Retrieved July 25,2008 from htpp://www.Uri.edu/artsci/wms/Hughes/mhvhealth.htm

Kangiwa, A.G., 2015. The Social-Economic Factors and Effects of Prostitution in Nigeria, European Journal in Social Sciences, 3:5, 70-82.

Kimberly, A., Workowski, S. B., 2010. Sexually Transmitted Diseases Treatment Guidelines. Atlanta: Emory University.

Misi, O. K., 2008. Nigeria: When University Become Brothers, Retrieved July 26, 2008 from htpp://www.Africanloft.com/University-orbrothel .

Mume, E., 2017. Prostitution in Nigeria's high schools. The pointer. Thursday, May 18.

National Action Committee on AIDS (2005): HIV/AIDS National Strategic Framework for Action 2005 - 2009. Nigeria NACA 2005, ADEA, Washington: The World Bank.

Okafor, H.C., Duru N.E., 2010. Sexual Promiscuity among Female Undergraduates in Tertiary Institutions in Imo State: An Issue for Healthy Living., Edo Journal of Counseling, 3:1, 100-109. 
Okoh, G., 2007. Nigeria: female Prostitution-The Case of Youths in Nasarawa. This Day Lagos $\left(4^{\text {th }}\right.$ October, 2007). All Africa Global Media (all Africa.com).

Olugbile, S., Abu., Adelakun., 2008. The Punch: Prostitution takes a New Garp on campuses. Punch on line Web Retrieved July 25, 2008 from htpp://www.punching.com/article.aspx? theatricart.

Olugbogega., 2008. Selling sex, female street Prostitution, And HIV risky behaviour care, htpp://www.searchlife.com.

Onwubiko, E., Okonkwo, S.N., 2013. Is prostitution a Menance? Thewillnigeria.com

Osoba, P., 1995. Be in Good Health. Benin; Osaba Publications. Ugwuegbulam, C. N. (2001), HIV/AIDS Guidance Services (A gender sensitive approach). Owerri; Joe Mankpaees Publishers.

Oyeoku ,E.K., 2012. Socio-Cultural and Economic Correlates of Prostitution Tendencies in South East Nigeria. A P.H.D Thesis Submitted to the Department of Educational Foundation, Faculty of Education, University of Nigeria Nsukka.

Oyeoku, E.K.., Ngwoke, D.U., Eskay, M., Obikwelu C.L., 2014. Perceived Impact of Prostitution Tendencies on Academic Performance of University Undergraduate in South East, Nigeria, Global Journal for Research Analysis, 3:1, 45-47.

Ukaegbu, B.C.N., Eze, I. L., Agomoh M.J., 2017. Economic Recession and Level of Female Prostitution in Selected Nigerian Universities, International Journal of Strategic Research in Education, Technology and Humanities, 4:1, 46-56.

Uzokwe, A. O., 2008. Nigerworld, prostitution in Nigeria campuses (part II) Retrieved July 21, 2008 from htpp://www.yahoo.com .

World Health Organisation., 1998. STD control in prostitution: Guidelines for policy. WHO consultation prevention and control of sexually transmitted diseases in population groups at risk. Geneva, Switzerland. 